\title{
Earthquake centre was victim of cash curbs
}

Washington. On 17 January, the very day of the Los Angeles earthquake, the National Science Foundation informed the Southern California Earthquake Center in the city that its annual grant is to be increased next year by $\$ 1$ million.

The NSF is hoping that the increase whose timing is said to be entirely coincidental - will take the heat out of charges that the centre, which now serves as the focal point of scientific investigation into the earthquake, was badly underfunded.

The 'open-walls' centre, based at the University of Southern California in South Central Los Angeles, is widely seen as a good example of the type of interdisciplinary research centre favoured by government agencies as a way of applying university research to specific problems - in this case, the risk of secondary earthquakes in the Los Angeles area.

Like other similar institutes in both the United States and elsewhere, the earthquake centre was set up as part of an ambitious scheme to divert tens of millions of dollars into such specialist research centres. But this ambition was deflated by fiscal pressure and complaints from scientists who feared such centres would take money away from other, more worthwhile projects.

Although some West Coast seismologists say the centre originally asked the NSF for up to $\$ 10$ million a year, its first formal application was for a grant of $\$ 5$ million. The NSF initially responded with an offer of $\$ 2.5$ million; once the foundation had dealt with a crisis over the funding its station in Antarctica, the earthquake centre actually ended up with $\$ 1.4$ million in 1991 .

Over the past three years, that has grown to $\$ 1.8$ million, and the NSF will provide the centre with $\$ 2.8$ million next year, in addition to $\$ 1.2$ million from the US Geological Survey.

Tom Henyey, the centre's executive director, has more patience with the founda- tion than some scientists in Los Angeles. He acknowledges that the NSF is torn between funding centres such as his, or providing grants for individual researchers. "They have to walk a fine line," he says.

The centre's goal is to construct a model of the area's seismology which is sufficiently accurate to allow for the probabilistic forecasting of earthquakes. Pursuing this goal involved bringing together geologists, seismologists, structural engineers and others for monthly meetings, for workshops on specific topics and for report writing.

Despite moderate funding - its budget is spread thinly among 50 principle investigators - the centre has attracted the participation of many earth scientists working locally. "We all come to the meetings," says Lucy Jones of the US Geological Survey at the California Institute of Technology.

"The centre is like a conscience," says Henyey. "A lot of earthquake preparedness is just getting the word out. It's not that we

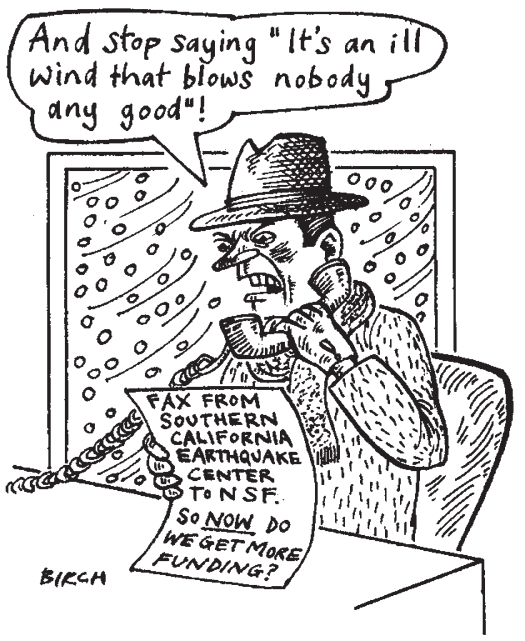

are going to come up with some great discovery; but we are coming to a better understanding of the earthquake potential in the Los Angeles basin."

\section{Russia holds on to science ministry}

Moscow. Despite the resignation of one of its most powerful supporters, the former first deputy prime minister Yegor Gaidar, Russia's Ministry of Science appears to have survived an attack from the Russian Academy of Sciences, and to have maintained its independence in the new government of President Boris Yeltsin.

According to a decree issued by the Russian president, the ministry is one of 23 departments which will make up the new government. At present, it appears that the former Minister of Science, Boris Saltykov, will remain in his post, although his future is by no means certain.

The attack from the academy took the form of a resolution passed by its praesidium in December, which blamed Saltykov for

\section{China promises to behave on patent protection}

Beijing. China has promised to introduce full protection for intellectual property as part of its bid to rejoin the group of countries covered by the General Agreement on Trade and Tariffs. (GATT).

The promise was made last month by Gao Lu-Lin, director-general of China's Patent Office, when be briefed a meeting of patent officers from all part of the country on China's latest effort to rejoin GATT countries and to bring its patent laws in line with those that have been adopted by other countries.

In the past, China reluctance to apply Western patent laws has become an increasing source of friction in its trade relations with the West, particularly the United States. In recent years, however, China has joined several international conventions on intellectual property.

Its officials maintain that the country has now fulfilled almost all of the intellectual property requirements necessary to be restored to its GATT membership.

"China must follow the GATT requirements if it wants to establish an economic presence in world markets." Gao Lu-Lin told last month's meeting. "Without international intellectual property protection, we will find it difficult to bring our technologies and products into world markets."

You Qin Li trying to destroy it. The resolution suggested that the ministry be replaced by a state committee - which could have allowed the academy to regain direct control of basic research activities which Saltykov has suggested should be funded independently.

But the academy's actions provoked a flow of letters to both President Yeltsin and his prime minister, Viktor Chernomyrdin, in support of the activities of the minister of science. In particular, one such letter was signed by the directors of nine of the country's largest scientific centres, describing the academy's attacks as "deeply erroneous".

The signatories of the letter included Spartak Belyaev, the director of the Institute of General and Nuclear Physics - the socalled Kurchatov Institute - of the Russian Scientific Centre; Igor Chuvila, director of the Institute of Theoretical and Experimental Physics; and Alexander Simonov, of the Karpov Physico-Chemical Institute.

The letter to Yeltsin endorsed Saltykov's attempts to move part of the funding of research projects on to a competitive basis, a moved which had been sharply criticized by the praesidium of the academy.

Other letters criticizing the leadership of the academy were received from the heads of all three of its regional branches, in Siberia, the Urals and the Far East. In addition, members of the academy based in Novosibirsk have written a joint letter to its president, Yuri Osipov, demanding new elections for all members of the praesidium - a proposal which is expected to be raised at its next general meeting. Vladimir Pokrovsky 